\title{
Emotional Intelligence as an Educational Strategy for Improving Employability Disabled People
}

\author{
Maria del Carmen Ortega-Navas* \\ Internationalization and Social Education, Spain
}

Submission: March 16, 2017; Published: April 24, 2017

*Corresponding author: Maria del Carmen Ortega-Navas, Vicedecana de Estudiantes, Internationalization and Social Education, UNED, Education Faculty Office 271, C/Juan del Rosal, 14, 28040, Madrid, Spain, Tel: (+34) 91-398-8873; Email: cortega@edu.uned.es

\section{Opinion}

The need to acquire, develop and update the competences of people with disabilities is strengthened, one of them, being Emotional Intelligence (IE here in after) as an educational, which will translate into a better qualification in the current demands on access to the labor market for people with disabilities. In fact, today, the globalization, the liberalization of markets, and the fall of trade and technological gates have made it necessary for students to increasingly strengthen their solid training at different levels: theoretical, practical and emotional [1].

The practice of EI as a competence in the field of education demonstrates that it can provide successful results in individual performance, in interpersonal relationships, in management work and in different areas of the lives of disabled people.

Among the measures to ensure the promotion of employment for people with disabilities must be taken into account in addition the environment (legislation, awareness raising through the reporting of social and economic agents), the economic aspects (recruitment subsidies, bonuses of employers contribution, adaptive aids to jobs), the technical support (depending on the disability and its degree), besides, the acquisition of educational competence, EI.

We must not forget that the integration of people with disabilities in companies is a current topic, so the fact, of hiring people with disabilities is an added value for companies that do, it is not to be isolated, from the initiatives that arise. More and more, in our society, is crucial to pay attention to the conditions of safety and health in the work of the people affected by some degree of their disability.

Nor should we forget the fact that people with disabilities have the skills and competences to successfully develop employment, provided that, like any other person, who are properly trained for their personal, academic, professional and social development. Thus, one aspect that must be taken into account when it comes to achieving a successful strategy for the inclusion of persons with disabilities in the work place is to show that they work on equal opportunities and that they are recognized as having a potential talent, being the practice of EI, therefore a fundamental educational strategy for the achievement of that objective, as we noted earlier.

Finally, the vision of the disability of people today has evolved. However, it is still essential that society continues to make progress in raising awareness of the importance of inclusion and diversity, as part of equal opportunities, for disabled people to enter the labor market, to provide thereby a decrease of educational and employment gap of people with disabilities.

\section{Conclusion}

Disability does not have to be a limitation for the success in the employability and the leadership in the educative and/ or labor scope. It is also worth noting that, as the progress of the acceptance of disability is one of the ongoing challenges, continues to be the achievement of real and effective equalization of equal opportunities for inclusion in all academic, work and social. In fact, for disabled people entering the workforce, not only improving their employability, but also insertion into employment, breaking the material and social barriers on the capacities of disabled people. In addition, we must keep in mind that it is advisable that the starting point of acceptance of the change of attitude towards the disabled person should be forged from the family nucleus, for the benefit not only of the disabled member but of the family in general, which will undoubtedly have a very positive impact on the academic and professional training of the disabled person in the first instance, and the rest of society too.

\section{References}

1. Ortega-Navas MC (2014) Improving employability in Higher Education students: the use of emotional intelligence as an educational strategy. Procedia-Social and Behavioral Sciences 139(2): 380-386. 
This work is licensed under Creative Commons Attribution 4.0 Licens DOI: 10.19080/GJIDD.2017.01.555557
Your next submission with Juniper Publishers will reach you the below assets

- Quality Editorial service

- Swift Peer Review

- Reprints availability

- E-prints Service

- Manuscript Podcast for convenient understanding

- Global attainment for your research

- Manuscript accessibility in different formats ( Pdf, E-pub, Full Text, Audio)

- Unceasing customer service

Track the below URL for one-step submission https://juniperpublishers.com/online-submission.php 